August 2007

\title{
Genocide and the International Court of Justice: Finally, a Duty to Prevent the Crime of Crimes
}

William A. Schabas

Follow this and additional works at: https://digitalcommons.usf.edu/gsp

\section{Recommended Citation}

Schabas, William A. (2007) "Genocide and the International Court of Justice: Finally, a Duty to Prevent the Crime of Crimes," Genocide Studies and Prevention: An International Journal: Vol. 2: Iss. 2: Article 2. Available at: https://digitalcommons.usf.edu/gsp/vol2/iss2/2

This Articles is brought to you for free and open access by the Open Access Journals at Digital Commons @ University of South Florida. It has been accepted for inclusion in Genocide Studies and Prevention: An International Journal by an authorized editor of Digital Commons @ University of South Florida. For more information, please contact digitalcommons@usf.edu. 


\title{
Genocide and the International Court of Justice: Finally, a Duty to Prevent the Crime of Crimes
}

\author{
William A Schabas \\ Professor of Human Rights Law, National University of Ireland, \\ Galway; Director, Irish Centre for Human Rights
}

\begin{abstract}
The International Court of Justice has issued its long-awaited decision in the suit filed by Bosnia and Herzegovina against Serbia and Montenegro with respect to the 1992-1995 war. The decision confirms the factual and legal determinations of the International Criminal Tribunal for the former Yugoslavia, ruling that genocide was committed during the Srebrenica massacre in July 1995 but that the conflict as a whole was not genocidal in nature. The Court held that Serbia had failed in its duty to prevent genocide in Srebrenica, although-because, the Court said, there was no certainty that it could have succeeded in preventing the genocide-no damages were awarded. The judgment provides a strong and authoritative statement of the general duty upon states to prevent genocide that dovetails well with the doctrine of the responsibility to protect.
\end{abstract}

The International Court of Justice (ICJ) is the principal judicial organ of the United Nations. ${ }^{1}$ It hears disputes between states and issues advisory opinions about legal issues at the request of other bodies within the UN system. All UN member states are parties to the Statute of the Court, which is integrated within the Charter of the United Nations, and are eligible to nominate judges. But the ICJ does not have automatic jurisdiction to hear cases involving those states. A state can only be sued by another state before the ICJ if it has formally accepted ICJ jurisdiction. States may do this by making a general declaration, pursuant to article 36(2) of the Statute of the International Court of Justice, but only about one-third of the members of the UN have done this. Some 300 specific treaties also provide that the ICJ is the venue for settlement of disputes concerning those treaties. Of these, perhaps the best known is the Convention for the Prevention and Punishment of the Crime of Genocide (UNCG), art. 9 of which states,

\footnotetext{
Disputes between the Contracting Parties relating to the interpretation, application or fulfilment of the present Convention, including those relating to the responsibility of a State for genocide or for any of the other acts enumerated in article 3, shall be submitted to the International Court of Justice at the request of any of the parties to the dispute. ${ }^{2}$
}

Invoking art. 9 of the UNCG, on 20 March 1993, as war raged on the territory of the former Yugoslavia, Bosnia and Herzegovina filed an application before the ICJ against what was then known as the Federal Republic of Yugoslavia. Bosnia and Herzegovina charged that Yugoslavia "had breached, and is continuing to breach, its legal obligations toward the People and State of Bosnia and Herzegovina under Articles I, II (a), II (b), II (c), II (d), III (a), III (b), III (c), III (d), III (e), IV and V of the

William A Schabas, "Genocide and the International Court of Justice: Finally, a Duty to Prevent the Crime of Crimes." Genocide Studies and Prevention 2, 2 (August 2007): 101-122. (C) 2007 Genocide Studies and Prevention. doi: 10.3138/gsp/001 
Genocide Convention." Article 9 had been invoked only once before, by Pakistan against India following the secession of Bangladesh, but the suit was dropped following negotiations between the parties. ${ }^{3}$ Since the Bosnian application of 1993, there have been several attempts to apply art. 9, but none has led to a final judgment involving interpretation of the substantive provisions of the UNCG. Consequently, the ICJ's judgment of 26 February 2007 in the case of Bosnia and Herzegovina $v$. Serbia and Montenegro constitutes a seminal event in the evolving law of genocide.

In its February 2007 ruling, ${ }^{4}$ the ICJ adopts a relatively narrow and conservative approach to the scope of the crime of genocide. It clearly distinguishes genocide from the cognate concept of "ethnic cleansing," following the general approach taken by the International Criminal Tribunal for the former Yugoslavia (ICTY) in its practice and judicial determinations. The ICTY, another UN judicial institution, was established by the Security Council in 1993 to deal with war crimes, crimes against humanity, and genocide committed on the territory of the former Yugoslavia since 1991. ${ }^{5}$ Although rejecting the charge that there was a general genocidal pattern during the conflict, for which Belgrade bore responsibility, the court acknowledges, in accordance with the findings of the ICTY, that the July 1995 Srebrenica massacre deserves the label "genocide." Many observers were dismayed by the court's relatively restrictive approach, which resulted in the dismissal of most of the allegations made by Bosnia and Herzegovina, a painful setback for the Bosnian Muslims, who suffered so terribly during the conflict. Some have tried to put a brave face on things, but for the Bosnians, if there was any victory here it was Pyrrhic in nature. Because the ICJ's jurisdiction is based solely on the UNCG, it has no residual authority to make determinations that other violations of international law, such as crimes against humanity (within which "ethnic cleansing" is easily subsumed), have been committed.

But this cloud has a silver lining. The court has made a major pronouncement on the duty to prevent genocide, declaring that this obligation, set out in exceedingly laconic terms both in the title and in art. 1 of the 1948 UNCG, requires states to take action when genocide is threatened outside their own territory, to the extent that they may be able to exercise some influence. It is a powerful message, with tremendous implications going well beyond the narrow finding that Serbia might have done more to avert the 1995 Srebrenica massacre. The court's approach to the duty to prevent genocide dovetails neatly with recent developments in the political bodies of the United Nations recognizing a "responsibility to protect," and it provides further support for the entrenchment of this doctrine within customary international law.

\section{Procedural Background to the Judgment}

Bosnia and Herzegovina had been a component republic of the Socialist Federal Republic of Yugoslavia since the latter's creation, in 1945, following World War II. The other republics were relatively homogenous in terms of ethnic composition, although they all had significant minority populations. In Bosnia and Herzegovina, on the other hand, there was no dominant ethnic group. Its multiethnic population consisted of large numbers of Serbs, Croats, and Muslims, although the Muslims were the largest group. As Yugoslavia was disintegrating, in the early 1990s, its large Serb minority favored amalgamating the Serb-dominated parts of Bosnia's territory with Serbia itself to create a "Greater Serbia." This idea was opposed by the other two ethnic groups, as well as by the European Union and other elements in the international community. Bosnia and Herzegovina seceded from Yugoslavia in April 1992, and armed conflict between the ethnic groups began almost immediately. 
The war was characterized by campaigns of what was soon labeled "ethnic cleansing," aimed at driving the various ethnic groups from their ancestral homes.

Bosnia and Herzegovina's application to the ICJ was filed on 20 March $1993 .^{6}$ When the application to the ICJ was initiated, Bosnia also sought provisional measures, pursuant to art. 41 of the Statute of the International Court of Justice, asking "[t]hat Yugoslavia (Serbia and Montenegro), together with its agents and surrogates in Bosnia and elsewhere, must immediately cease and desist from all acts of genocide and genocidal acts against the People and State of Bosnia and Herzegovina."7 Yugoslavia (Serbia and Montenegro) replied with a request that the court order provisional measures against Bosnia and Herzegovina, including directions to leave Serb towns alone and to cease destruction of Orthodox churches and places of worship and of other Serb cultural heritage, and that the government of Bosnia "put an end to all acts of discrimination based on nationality or religion and the practice of 'ethnic cleansing,' including the discrimination related to the delivery of humanitarian aid, against the Serb population in the 'Republic of Bosnia and Herzegovina." "8

On 8 April 1993, the court ordered provisional measures against Yugoslavia (Serbia and Montenegro) and indicated that neither party should take action that might aggravate or extend the dispute. The Court held that art. 9 of the UNCG appears

to afford a basis on which the jurisdiction of the Court might be founded to the extent that the subject-matter of the dispute relates to "the interpretation, application or fulfilment" of the Convention, including disputes "relating to the responsibility of a State for genocide or for any of the other acts enumerated in article III of the Convention."

The court's order stated that "there is a grave risk of acts of genocide being committed."10

On 27 July 1993, Bosnia and Herzegovina applied once again to the ICJ for additional provisional measures. The application focused on issues arising from the arms embargo placed upon the entire region by the UN Security Council. Bosnia and Herzegovina asked the court to declare

[t]hat in order to fulfil their obligations under the Genocide Convention under the current circumstances, all Contracting Parties thereto must have the ability to provide military weapons, equipment, supplies and armed forces (soldiers, sailors, airpeople) to the Government of Bosnia and Herzegovina at its request. ${ }^{11}$

Yugoslavia again answered with its own request for provisional measures, seeking an order against the "so-called Republic of Bosnia and Herzegovina" that it "take all measures within its power to prevent commission of the crime of genocide against the Serb ethnic group." 12 The court concluded, unanimously, that Yugoslavia (Bosnia and Herzegovina) "should immediately, in pursuance of its undertaking in the Convention on the Prevention and Punishment of the Crime of Genocide of 9 December 1948, take all measures within its power to prevent commission of the crime of genocide" and more specifically that it should

ensure that any military, paramilitary or irregular armed units which may be directed or supported by it, as well as any organizations and persons which may be subject to its control, direction or influence, do not commit any acts of genocide, of conspiracy to commit genocide, of direct and public incitement to commit genocide, or of complicity in genocide, whether directed against the Muslim population of Bosnia and Herzegovina or against any other national, ethnical, racial or religious group. ${ }^{13}$ 
The court refused the applicant's request that it also consider the Treaty between the Allied and Associated Powers and the Kingdom of Saint-Germain-en-Laye of 10 September 1919, as well as the customary and conventional international laws of war and international humanitarian law, as a basis for the litigation. ${ }^{14}$

Shortly after the issuance of the second provisional measures order, Bosnia declared its intention to institute proceedings against the United Kingdom, based on the latter's obligation to prevent genocide. Its statement charged the United Kingdom was "jointly and severally liable for all of the harm that has been inflicted upon the People and State of Bosnia and Herzegovina because the United Kingdom is an aider and abettor to genocide under the Genocide Convention and international criminal law." 15 The United Kingdom replied, on 6 December, that the application was without foundation, and on 17 December 1993 Bosnia and Herzegovina informed the Security Council of its decision not to proceed against the United Kingdom.

Litigation before the ICJ typically has two phases. The first addresses preliminary objections from the defendant or respondent state. Serbia and Montenegro contested the court's authority to rule on the Bosnian application; its preliminary objections were dismissed by the court on 11 July $1996 .{ }^{16}$ Once the preliminary issues had been resolved, the case should then have proceeded to a ruling on the merits of the application within a reasonable time. In fact, however, it would take more than a decade for the court to issue its final judgment, an extraordinary delay even for an institution accustomed to working at a leisurely pace. The primary reason for this delay was division within the government of Bosnia and Herzegovina about whether to proceed with the case. Since the December 1995 Dayton Peace Agreement, representatives of the Serb entity within Bosnia and Herzegovina have participated in the national government. When they were in positions of responsibility within the foreign ministry, there were attempts to withdraw the case. Although ultimately unsuccessful, these initiatives did delay the progress of the case toward hearing and judgment.

Other issues also helped to delay the case. After the 1996 admissibility ruling, Serbia and Montenegro filed what is known as a counter-claim, in effect arguing that Bosnia, too, had committed genocide against Serb populations. Although the counterclaim was eventually withdrawn, valuable time was devoted to addressing the issues it raised. ${ }^{17}$ More important was a dispute about whether or not Serbia and Montenegro was actually a member of the United Nations during the relevant period. This had not been properly addressed in the early stages of the case, and the dispute came to a head only after 2000, when Serbia and Montenegro was admitted to the United Nations as a new member state.

When states break up, normally one of the component parts is recognized as the "continuator" of the legal personality of its predecessor. Thus, when the Soviet Union collapsed in the early 1990s, Russia-rather than, say, Kazakhstan or Latvia-retained the legal rights and obligations of the Soviet Union. Russia, and not Kazakhstan or Latvia, took on the USSR's permanent seat in the UN Security Council, for example. When Yugoslavia collapsed, many assumed that Serbia and Montenegro would continue the legal personality of the previous state. But, unlike the case of the Soviet Union, the situation was muddied by the suspension of Yugoslavia from the United Nations as a sanction for its belligerent conduct. If the Belgrade regime was not a member of the United Nations, then it was also excluded from the ICJ and was not a party to the UNCG. And this meant that the court could not validly exercise its jurisdiction. 
In 2001, following its admission to the United Nations, Serbia and Montenegro asked the ICJ to revise its 1996 judgment on admissibility, on the grounds that at the time it had not been a member of the United Nations and therefore could not have been a party to the Statute of the International Court of Justice. Moreover, Serbia and Montenegro argued that it became a party to the UNCG only on 8 March 2001 and, moreover, that its accession to the convention included a reservation to art. 9. In its judgment of 3 February 2003, the Court ruled the application for revision inadmissible, stating that, in accordance with art. 61(1) of its statute, it could revise an earlier judgment only "based upon the discovery" of some fact which, "when the judgment was given," was unknown. Serbia had argued that its admission to the United Nations in 2000 was such a "new fact." The court, however, said that

[a] fact which occurs several years after a judgment has been given is not a "new" fact within the meaning of Article 61; this remains the case irrespective of the legal consequences that such a fact may have. ${ }^{18}$

Nevertheless, the court returned to this question in its February 2007 judgment on the merits of the case.

By then, the matter had been further complicated as a result of a ruling by the ICJ in a totally separate case. In 1999, as bombs fell on Belgrade, Serbia and Montenegro invoked art. 9 of the UNCG and sued several NATO states before the ICJ. Belgrade's argument on the substance of the claim bordered on the frivolous, but it had a good case with respect to another aspect of the application, namely that the NATO states had breached the UN Charter by using force in the absence of any Security Council authorization. The court never ruled on the merits, dismissing the entire claim because, it said, Serbia and Montenegro had not been a member of the United Nations in 1999:

at the time of filing of its Application to institute the present proceedings before the Court on 29 April 1999, the Applicant in the present case, Serbia and Montenegro, was not a Member of the United Nations, and consequently, was not, on that basis, a State party to the Statute of the International Court of Justice. It follows that the Court was not open to Serbia and Montenegro. ${ }^{19}$

In its February 2007 judgment, however, the court rejected Serbia's argument on this point. On the surface, at least, this looks like a blatant example of double standards: when Serbia sues, it doesn't exist, but when it is sued, it exists. The court said that it could not dismiss the Bosnian application on the grounds that Serbia and Montenegro had not been a member of the United Nations during the 1990s because it had already decided the contrary in its 1996 decision on preliminary objections in the case. The court invoked a Latin maxim, res judicata, which means that once a matter has been litigated and resolved between two parties, it cannot be reopened. ${ }^{20}$ A corollary of the concept, known by the name "double jeopardy," is well known to non-specialists. The res judicata determination is one of the profoundly unsatisfactory elements of the judgment, and it will hardly enhance the credibility of the court's ruling among the Serbs, for whom it can only bolster the sense of victimization by hypocritical international institutions. The blow is softened by the fact that Serbia fared rather well on the merits of the case. Several judges on the court were plainly embarrassed by the res judicata argument and appended individual opinions indicating that it would have been preferable to dismiss the Bosnian application outright and for the same reasons that the court had earlier rejected Serbia's claim against the NATO states. $^{21}$ 


\section{The Scope of Article 9 of the UNCG}

Article 9 of the UNCG gives the ICJ jurisdiction over disputes between states about "the interpretation, application or fulfilment" of the convention. Whether this provision encompasses charges that a state has actually committed genocide has been a matter of some dispute over the years. It is part of an even larger debate about whether states actually can commit crimes, including genocide. At Nuremberg, the judges of the International Military Tribunal famously said, "Crimes against international law are committed by men, not by abstract entities, and only by punishing individuals who commit such crimes can the provisions of international law be enforced." 22 The International Law Commission, a subsidiary organ of the UN General Assembly with responsibility for the codification and progressive development of international law, has declined to resolve the issue of whether socalled state crimes fall within the broader rubric of "state responsibility." "23

The court settled this dispute by concluding that states can indeed commit the crime of genocide and that charges on this basis fall within the scope of art. 9 of the UNCG. Here it distinguishes between the general proposition, in art. 1, to "undertake to prevent and to punish" the crime of genocide and the obligations set out in arts. 5-7 concerning the prosecution of genocide, the adoption of effective legislation, and cooperation in extradition. The court states that art. 1 is "not merely hortatory or purposive." 24 Thus, in addition to the obligation to punish, to which several more specific provisions of the UNCG are addressed, there is also an obligation to prevent. Nevertheless, the court concedes that the convention does not expressly impose an obligation upon states not to commit genocide. ${ }^{25}$ It concludes that such an obligation exists as a necessary corollary of the obligation to prevent:

Under Article I the States parties are bound to prevent such an act, which it describes as "a crime under international law," being committed. The Article does not expressis verbis require States to refrain from themselves committing genocide. However, in the view of the Court, taking into account the established purpose of the Convention, the effect of Article I is to prohibit States from themselves committing genocide. Such a prohibition follows, first, from the fact that the Article categorizes genocide as "a crime under international law": by agreeing to such a categorization, the States parties must logically be undertaking not to commit the act so described. Secondly, it follows from the expressly stated obligation to prevent the commission of acts of genocide. That obligation requires the States parties, inter alia, to employ the means at their disposal, in circumstances to be described more specifically later in this Judgment, to prevent persons or groups not directly under their authority from committing an act of genocide or any of the other acts mentioned in Article III. It would be paradoxical if States were thus under an obligation to prevent, so far as within their power, commission of genocide by persons over whom they have a certain influence, but were not forbidden to commit such acts through their own organs, or persons over whom they have such firm control that their conduct is attributable to the State concerned under international law. In short, the obligation to prevent genocide necessarily implies the prohibition of the commission of genocide. ${ }^{26}$

The court next examined whether the parties to the convention are also under an obligation, by virtue of the convention, not to commit genocide themselves. It must be observed at the outset that such an obligation is not expressly imposed by the actual terms of the convention. The court reviewed the drafting history and other materials to support its conclusion that states are under an obligation not to commit the crime of genocide and that they incur their state responsibility should they violate this duty. "[I]f an organ of the State, or a person or group whose acts are legally attributable to 
the State, commits any of the acts proscribed by Article III of the Convention, the international responsibility of that State is incurred," the judgment concludes. ${ }^{27}$ The Court itself seemed to acknowledge that the answer is not obvious. Some judges also dissented on this issue, further evidence of the difficulty the question raises. ${ }^{28}$

Thus, the court concluded that parties to the UNCG "are bound not to commit genocide, through the actions of their organs or persons or groups whose acts are attributable to them." 29 This conclusion applies both to the crime of genocide itself, which is defined in art. 2 of the UNCG, and to the four other punishable acts listed in art. 3, namely conspiracy, attempt, direct and public incitement, and complicity. Replying to the argument that international law does not recognize the concept of state crimes, the court said that it was ruling on issues of state responsibility, not state criminality, referring to what it calls "duality of responsibility" 30 and noting art. 25(4) of the Rome Statute of the International Criminal Court (ICC), which declares that "No provision in this Statute relating to individual criminal responsibility shall affect the responsibility of States under law." "T1 The court also found support for its position in the drafting history of the UNCG. The arguments submitted by Serbia were not devoid of any merit, and they spoke to a legitimate controversy in the interpretation of the convention. The court's analysis helpfully clarifies the matter and should largely resolve any disputes on this point in the future.

\section{The Burden of Proof}

Cases before the ICJ usually involve facts that are largely uncontested. The hearings are generally not trials, at which evidence is produced and disputed. Bosnia $v$. Serbia was an exception. As a preliminary matter, the court made some important and controversial determinations about principles and rules of evidence.

There was particular debate about Serbia's production of documents emanating from its Supreme Defense Council. These materials had been "redacted"; that is, portions of them had been blacked out. Serbia's justification for failing to provide the court with the entire documents was the protection of its national security interests. Theoretically, the court was empowered to order the production of these materials, in accordance with art. 49 of its statute. ${ }^{32}$ But it did not exercise these powers against Serbia. Furthermore, Bosnia invited the court to draw negative inferences from Serbia's refusal, and one of the judges, in a dissenting opinion, agreed with this proposal. ${ }^{33}$ To the dismay of the applicants, however, the court did not attach any special and pejorative significance to the Serbian position. The court's reticence may have been driven by concern about the long-term policy implications of demanding that states produce evidence over and above their national security concerns, a matter of great sensitivity. In an early ruling, the Appeals Chamber of the ICTY insisted that international judges, not governments, would be the arbiters of national security concerns. ${ }^{34}$ The ruling terrified many states, and several months later, when they were drafting the Rome Statute, they made sure that no such power of judges was recognized. ${ }^{35}$ Were the court to set a precedent in a case involving confidential documents in the archives in Belgrade, the same approach would have to apply to the CIA, MI6, and the Sûreté, at least theoretically. Wise judges often rule not so much on the basis of the situation immediately before them as in contemplation of the eventual consequences rulings may have on imagined future disputes.

The ICJ's discussion of the standard or burden of proof reveals the complexity of the issues, which seem to straddle an unclear distinction between state responsibility for international crimes and individual criminal responsibility. One aspect of this 
difficulty has already been discussed, namely, whether or not a state can commit genocide. In a compromise formulation, the court declares that a state can violate the UNCG by perpetrating genocide, although it states that by so doing the state engages its responsibility in a classic international law sense, rather than saying that it commits a "state crime." With respect to evidence, Bosnia and Herzegovina argued that because the matter was one of state responsibility and not criminal liability, the court should apply the ordinary standard of proof, usually described as the "balance of probabilities" or the "preponderance of evidence"; this means that the court must accept the applicant's version of the facts to the extent that it is more likely than the respondent's to be true. Serbia and Montenegro argued, on the contrary, that because of the nature of the litigation, involving charges of state responsibility for what is arguably the crime of crimes, the applicant should be required to prove its case beyond a reasonable doubt, which is the standard of proof normally used in criminal proceedings. ${ }^{36}$ For example, art. 66(3) of the Rome Statute says that "[i]n order to convict the accused, the Court must be convinced of the guilt of the accused beyond a reasonable doubt." 37

Without expressly adopting either formulation, the court's judgment definitely favors the approach proposed by Serbia: "In respect of the Applicant's claim that the Respondent has breached its undertakings to prevent genocide and to punish and extradite persons charged with genocide, the Court requires proof at a high level of certainty appropriate to the seriousness of the allegation." ${ }^{38}$ This conclusion is of crucial importance, to the extent that the Bosnians were relying upon evidence presented to the ICTY, where the "beyond reasonable doubt" norm applies, ${ }^{39}$ but asking the ICJ to draw different conclusions pursuant to a lower standard of proof. To the extent that the court adopted a standard of proof analogous to the "reasonable doubt" requirement of criminal tribunals, this would enhance the likelihood that it would also reach the same conclusions on issues of fact-and this is indeed what happened.

The "high level of certainty appropriate to the seriousness of the allegation" standard of proof is an innovation in the jurisprudence of the ICJ. In December 2005, the ICJ ruled on charges by the Democratic Republic of Congo against Uganda that were framed in the language of human-rights law rather than that of international criminal law. The court then said it had "credible evidence sufficient to conclude" that Ugandan forces had committed various violations of human rights, although these might well also have been described as international crimes: acts of killing, torture, and other forms of inhumane treatment of the civilian population; destruction of villages and civilian buildings; failure to distinguish between civilian and military targets and to protect the civilian population in fighting with other combatants; incitement of ethnic conflict; and training of child soldiers. ${ }^{40}$ In fact, the terminology in both cases is novel; arguably, the court raised the burden of proof when it moved from "credible evidence sufficient to conclude" in Congo $v$. Uganda to a "high level of certainty" in Bosnia v. Serbia. The distinction is unfamiliar to lawyers and probably mystifyingly semantic to others.

There is some merit on both sides of this debate, but ultimately the court's approach seems wise, albeit frustrating for those who seek to invoke the UNCG in noncriminal proceedings. The rationale for such a high burden of proof in criminal justice is the gravity of the consequences. A finding of genocide against a state, although it cannot result in a loss of liberty, as is the case with an individual defendant, brings with it a terrible stigma, not to mention potentially enormous financial liabilities. 
It makes sense, then, that a comparably high standard of proof be imposed when a finding of genocide is sought against a state. The other benefit of this approach is that it brings a degree of coherence to litigation concerning genocide. It hardly seems desirable for criminal courts to acquit upon charges of genocide while tribunals addressing state responsibility for genocide reach the opposite result, essentially on the basis of technical legal distinctions that would be poorly understood by nonspecialists. The dichotomy between levels of proof is familiar to lawyers trained in the common law, where apparently contradictory rulings based on different standards of proof are well known (recall O.J. Simpson's acquittal for murder and his subsequent condemnation, before a civil court, for "wrongful death"). In legal systems based on continental models, civil and criminal justice are often joined in one proceeding, precisely to ensure a single ruling on the core issue. Although indirectly, this seems to be what the ICJ has done, too.

\section{Distinguishing Ethnic Cleansing and Genocide}

So-called ethnic cleansing and genocide should not be confounded, says the ICJ. It observes that "ethnic cleaning" has often been used to describe the events in Bosnia and Herzegovina, referring, for example, to the final report of the UN Commission of Experts $^{41}$ and to a General Assembly resolution. ${ }^{42}$ The court might have added a reference to one of the individual opinions accompanying its provisional measures ruling issued in 1993, when the application was first filed. ${ }^{43}$ According to the court, the expression "is in practice used, by reference to a specific region or area, to mean 'rendering an area ethnically homogeneous by using force or intimidation to remove persons of given groups from the area." 44 The court notes that not only is the term not used in the UNCG but a proposal during the drafting aimed at including "measures to oblige members of a group to abandon their homes in order to escape the threat of subsequent ill-treatment" 45 was not accepted. Accordingly, said the court,
[n]either the intent, as a matter of policy, to render an area "ethnically homogeneous," nor the operations that may be carried out to implement such policy, can as such be designated as genocide: the intent that characterizes genocide is "to destroy, in whole or in part" a particular group, and deportation or displacement of the members of a group, even if effected by force, is not necessarily equivalent to destruction of that group, nor is such destruction an automatic consequence of the displacement. ${ }^{46}$

Once again, the court's position is consistent with pronouncements of the ICTY, which are referred to in the judgment. For example, in Krstic', the Trial Chamber said that although "there are obvious similarities between a genocidal policy and the policy commonly known as "ethnic cleansing," "47 "[a] clear distinction must be drawn between physical destruction and mere dissolution of a group. The expulsion of a group or part of a group does not in itself suffice for genocide." ${ }^{48}$ It cannot be gainsaid, however, that views have been expressed, both within case law and in academic writing, ${ }^{49}$ supporting a more liberal interpretation by which genocide and "ethnic cleansing" are merged. In Krstić, Judge Shahabuddeen of the Appeals Chamber leaned in this direction. ${ }^{50}$ His views were subsequently echoed-and, moreover, amplified-in a ruling by one of the ICTY Trial Chambers, in which the judges argued that "ethnic cleansing" should be subsumed within the crime of genocide. ${ }^{51}$ Indeed, it is precisely because this debate persists that the ICJ's February 2007 ruling is so helpful. It should largely resolve the controversy. 


\section{Establishing the Intent to Commit Genocide}

Much of the ICJ's attention was taken up with establishing the mental element of the crime of genocide. The court explains that the crime of genocide involves not only the intent to commit the underlying act, such as killing, but also that the act be done with the intent to destroy the group. It is not enough, says the court, that the perpetrator possess a discriminatory intent. The court compares genocidal intent with that of the related crime against humanity of persecution. ${ }^{52}$ These statements are not particularly controversial, to the extent that they are largely based on familiar pronouncements in the case law of the ICTY.

The literature on this subject is enormous, as are the statements of the ad hoc tribunals. The difference, though, is that the court was looking for the mental element through the lens of state responsibility. It was asking whether Serbia (or the Republika Srpska) possessed the "mental element" for the commission of genocide, rather than whether this was the case for any particular individual. The closest we have come in the past to such analysis is the report of the Darfur Commission, mandated by the UN Security Council to consider whether genocide was being committed in Sudan. ${ }^{53}$

But can a state have a "mental element"? Certainly, the analogy with individuals, in whose case concepts of knowledge and intent are relatively well understood in national criminal law and easily transposable to an international context, is only very approximate. In practice, what we look for is not a "mental element" but, rather, a "plan or policy." In its February 2007 judgment, the ICJ observes that the material element of the crime of genocide may have been present but that it had not been "conclusively established that the massive killings of members of the protected group were committed with the specific intent (dolus specialis) on the part of the perpetrators to destroy, in whole or in part, the group as such."54 But in reality, the court was looking for evidence of a plan or policy. Otherwise, it would be required to consider the hypothesis that a single individual, acting alone, might have committed one of the acts with a genocidal specific intent. The ICJ does not indulge in such inquiry, but the question has engaged others who have asked whether genocide was committed, including the ICTY. ${ }^{55}$ Similarly, the Darfur Commission does not exclude the possibility of lone perpetrators. ${ }^{56}$

But both the Darfur Commission and the ICJ have looked, in practice, to state policy. Absent evidence of such a policy, they conclude that genocide was not committed. A similar discussion has taken place with respect to crimes against humanity. After noting that "[t]here has been some debate in the jurisprudence of this Tribunal as to whether a policy or plan constitutes an element of the definition of crimes against humanity," the Appeals Chamber of the ICTY has said that practice "overwhelmingly supports the contention that no such requirement exists under customary international law." " One justification for its position is the earlier conclusion that a plan or policy is not required to establish the crime of genocide.

Article 2 of the UNCG does not say anything about a policy element, and this has led many commentators and judges to the conclusion that it is not an element of the crime. With respect to crimes against humanity, the question is a bit more complicated: although the Appeals Chamber of the ICTY ruled, in Kunarac, that this was not part of customary law, it did not mention art. 7(2)(a) of the Rome Statute, which suggests the opposite when it states that "'attack directed against any civilian population' means a course of conduct involving the multiple commission of acts referred to in para. 1 against any civilian population, pursuant to or in furtherance of a 
State or organizational policy to commit such attack." Along somewhat the same lines, the Elements of Crimes of the Rome Statute require that genocidal acts "took place in the context of a manifest pattern of similar conduct directed against that group or was conduct that could itself effect such destruction."58 This component was adopted in reaction to a ruling from a Trial Chamber of the ICTY that an individual, acting alone, could perpetrate genocide.

Cherif Bassiouni has argued, in my view quite persuasively, that we have got the definition of crimes against humanity upside down. He says that the "widespread or systematic" elements, set out in art.7(1) of the Rome Statute and well established in customary law, are better viewed as means of proving the state plan or policy. In other words, the truly distinguishing element of crimes against humanity is the fact that they are part of a state plan or policy rather than that they are widespread or systematic. $^{59}$ This makes perfect sense when one realizes that the designation "crimes against humanity" was originally designed to capture crimes of state that went unpunished precisely because the state was complicit in them: it was a way of addressing state crimes, not perverse individuals, although it was premised on judging and punishing the individuals responsible for such policies. The International Military Tribunal never addressed the issue of plan or policy directly, and the reason is obvious: the Nazi plan and policy to wage aggressive war and to exterminate the Jews of Europe underpinned the entire case. Why would the tribunal ever have even spoken to the issue, under the circumstances?

Why would the same reasoning not apply to genocide? Thus, the so-called mental element, although worded in criminal law terminology, is actually an attempt to define the content of the state plan or policy. By this logic, a state would be found to have committed genocide if there were evidence of a plan or policy indicating an intent to destroy, in whole or in part, a national, ethnic, racial, or religious group as such. In effect, this is what the ICJ and the Darfur Commission have done. They have searched not for the mens rea of an individual but, rather, for the policy of a state.

\section{Was Genocide Committed in Bosnia?}

The judgment of the ICJ concludes that genocide was not committed during the conflict in Bosnia and Herzegovina between 1992 and 1995, with the exception of the Srebrenica massacre in mid-July 1995. At Srebrenica, Bosnian Serb military units directed by General Ratko Mladić were responsible for the summary execution of approximately 7,000 Muslim men and boys over the course of several days. On the nonSrebrenica charges, the court states,

[I]t is established by overwhelming evidence that massive killings in specific areas and detention camps throughout the territory of Bosnia and Herzegovina were perpetrated during the conflict. Furthermore, the evidence presented shows that the victims were in large majority members of the protected group, which suggests that they may have been systematically targeted by the killings. The Court notes in fact that, while the Respondent contested the veracity of certain allegations, and the number of victims, or the motives of the perpetrators, as well as the circumstances of the killings and their legal qualification, it never contested, as a matter of fact, that members of the protected group were indeed killed in Bosnia and Herzegovina. The Court thus finds that it has been established by conclusive evidence that massive killings of members of the protected group occurred and that therefore the requirements of the material element, as defined by Article II (a) of the Convention, are fulfilled...

The court is however not convinced, on the basis of the evidence before it, that it has been conclusively established that the massive killings of members of the protected 
group were committed with the specific intent (dolus specialis) on the part of the perpetrators to destroy, in whole or in part, the group as such. The court has carefully examined the criminal proceedings of the ICTY and the findings of its chambers, cited above, and observes that none of those convicted were found to have acted with specific intent (dolus specialis). The killings outlined above may amount to war crimes and crimes against humanity, but the court has no jurisdiction to determine whether this is so. In the exercise of its jurisdiction under the Genocide Convention, the Court finds that it has not been established by the Applicant that the killings amounted to acts of genocide prohibited by the Convention. ${ }^{60}$

These findings should come as no surprise to anyone familiar with the case law and the practice of the ICTY. In two cases concerning Srebrenica, the tribunal has convicted defendants of aiding and abetting genocide. It has held that while the accused, General Radislav Krstić and Colonel Vidoje Blagojević, did not themselves intend to commit genocide, they assisted the units controlled by General Mladić, knowing of his genocidal plans. ${ }^{61}$ Otherwise, the tribunal has consistently acquitted persons charged with genocide with respect to "ethnic cleansing" and the atrocities perpetrated in concentration camps during the conflict. The accused were invariably convicted of crimes against humanity instead. ${ }^{62}$ Moreover, the Office of the Prosecutor had often indicated its ambivalence on the subject by declining to charge genocide, in many cases, or by withdrawing genocide indictments in exchange for a guilty plea. 63

Bosnia and Herzegovina had presented indictments alleging genocide in support of its claim, but the court quite correctly noted that the fact the prosecutor might charge genocide was of little real weight. What mattered, said the court, was the prosecutor's decision not to include a genocide charge, or to remove it by amendment subsequently if it had been included initially. ${ }^{64}$ The prosecutor declined charging Serbian President Slobodan Milošević with genocide with respect to Kosovo. ${ }^{65}$ Even more striking was the decision to withdraw genocide charges against Biljana Plavšić, one of the Bosnian Serb leaders at the height of the conflict. ${ }^{66}$ If she was not responsible for genocide, then who was? When all of this was added up, it should have been clear to the lawyers for Bosnia that their case sat on a fragile footing. One detail of prosecutorial practice that escaped the court's attention, although it only confirmed its general vision, was the failure of the prosecutor to appeal a genocide acquittal, evidence once again of the ambiguities of the court's approach. ${ }^{67}$ Perhaps there was a forlorn but ultimately misguided hope that the ICJ would "correct" its neighbor, the ICTY. But it did nothing of the sort, instead showing great respect for the expertise of that institution on issues of both fact and law.

Certainly, the ICJ endorsed the conclusion that genocide had been perpetrated at Srebrenica. Here too, though, it followed the analysis of the ICTY, treating the massacre as an isolated and ultimately idiosyncratic event within a broader conflict whose essence was not fundamentally genocidal, a devastating and destructive attack on the Muslims of Srebrenica that was improvised at the last minute by General Mladic. That made the link much harder to draw between the Bosnian Serb soldiers in Srebrenica and President Milošević, far away in the Serb capital. Not only has nobody found the smoking gun to link Belgrade with the crime, it seems unlikely and implausible that one existed. The unfinished trial of Milošević never succeeded in joining up the dots to link him to Srebrenica. ${ }^{68}$ In fact, much of the evidence in that proceeding pointed to a rift between Belgrade and the Bosnian Serb leaders, rather than to the fabled conspiracy. 
Counsel for the Bosnians relied heavily upon the findings of the ICTY, yet at the same time asked the court to go beyond these. For example, whereas the tribunal had convicted General Stanislav Galic for crimes against humanity and war crimes with respect to the shelling and sniping of Sarajevo, Bosnia wanted the ICJ to go further and characterize such acts as genocide. This the ICJ refused to do. On this point, the court noted that Serbia had conceded that crimes were committed during the siege of Sarajevo that "could certainly be characterized as war crimes and certain even as crimes against humanity."69

The court took an exceedingly deferential approach to the findings of the ICTY, in effect acknowledging the latter's expertise on issues both of fact and of law. Only when the tribunal ventured beyond the parameters of international criminal law and into the realm of state responsibility did the ICJ graciously rebuke it. ${ }^{70}$ Counsel for Serbia and Montenegro seemed to appreciate this, for they quietly changed their attitude toward the findings of the ICTY as the litigation advanced. Initially the Serbs had been dismissive of the ICTY, but they became more comfortable with the case law as they realized that judges in The Hague were failing to convict for genocide. This evolution in the position of Serbia and Montenegro did not escape the notice of the ICJ. ${ }^{71}$

The ICJ's deferential approach to the ICTY is a welcome development in terms of clarifying the relationship between the two bodies; it addresses recent concerns about a "fragmentation" of international law resulting from a proliferation of courts, tribunals, and similar institutions. Yet, by adopting virtually uncritically the findings in fact and law of the tribunal, the ICJ also perpetuates contradictions within that very jurisprudence. That the ICJ was not unaware of some of the difficulties with the ICTY case law is perhaps revealed in its somewhat equivocal concluding remark on the Srebrenica genocide issue: "The Court sees no reason to disagree with the concordant findings of the Trial Chamber and the Appeals Chamber."72 Perhaps a more affirmative statement might have been expected, under the circumstances.

The inconsistencies in the case law of the ICTY are apparent from an examination of the two important Trial Chamber judgments adopted in the wake of the Appeals Chamber's April 2004 ruling in Krstić, which dealt with Srebrenica. One Trial Chamber, in Blagojević, took an exceedingly large and liberal approach to the concept of genocide, one capable of including a range of acts of "ethnic cleansing."73 The other, in Brtanin, hewed to the more restrictive approach and dismissed a charge of genocide. ${ }^{74}$ It may well be argued that Brtanin is consistent with the majority in Krstić, whereas Blagojevic follows the dissent of Judge Shahabuddeen in Krstić. But that this diversity in the case follows what should have been a definitive ruling of the Appeals Chamber reveals uncertainty within the tribunal itself about what Krstic resolved. Of interest here are statements from the presiding judge in Popović et al., a multi-defendant trial concerning the Srebrenica massacre currently underway before the ICTY. At the ICTR in Arusha, judges have taken "judicial notice" of the Rwandan genocide, in effect making proof thereof unnecessary in future cases. ${ }^{75}$ But in Popovic, even after the ICJ ruling, the ICTY resisted the temptation to declare that there would be no further debate as to whether genocide had been committed at Srebrenica in July 1995.

The Appeals Chamber judgment in Krstic is indeed problematic, and its internal contradictions reveal major differences among the judges themselves. It did not, after all, convict General Krstić of genocide. It endorsed a vision of the Srebrenica "genocide" by which the killings were not planned and organized but, rather, were improvised in the course of a few days by General Mladić. Even then, of course, the 
Srebrenica massacre was accompanied by the evacuation of women and children. This was, in fact, the responsibility of General Krstić. At its best, the evacuation was a humanitarian gesture; taken at its worst, it amounted to ethnic cleansing. But was it genocide? Do those who seek to destroy an ethnic group not ensure that the women and children, above all, do not survive? That, at least, is how génocidaires behaved in Nazi Germany and in Rwanda. As for the massacre of the men of military age, the so-called genocidal act at the heart of the Srebrenica atrocities, this too is an act shrouded in ambiguity. Murdering prisoners of war is, of course, an atrocious and unpardonable war crime. But it does not unequivocally reveal an intent to destroy an ethnic group.

The Krstic' Appeals Chamber seemed to reach an unsatisfactory compromise, rejecting the idea that "ethnic cleansing" could amount to genocide, but then concluding that acts that might well be described as "ethnic cleansing" should be labeled genocide. The way to cut the Gordian knot was for the Appeals Chamber to contend that the intent was to destroy Muslim life in Srebrenica. But surely the evacuation of a population, that is, ethnic cleansing, does precisely this. There were implausible suggestions that killing the men would prevent the community from reproducing itself. But if this was really the Serbs' intent, why did they spare the boys? Certainly contemporary history has shown that if the Serbs believed they could physically destroy the Muslims of Srebrenica in this manner, they were making a gross miscalculation. According to recent reports, Muslim life in Srebrenica is now more vital and dynamic than ever.

None of this should be taken as an attempt to diminish the horror of the Srebrenica massacre. The summary execution of the men of a community, coupled with the expulsion of the women and children, is a horrific crime against humanity. Nevertheless, if the theoretical construct of the crime of genocide proposed by the ICTY and endorsed by the ICJ is to be sustained, it would have been more consistent and coherent to conclude that Srebrenica, too, was not an act of genocide. Both the ICTY and the ICJ seem to want to have their cake and to eat it too, espousing a rigorous legal analysis of the elements of the crime but nevertheless bowing to the crowd by acknowledging the most outrageous act in the entire war as rising to the level of genocide.

\section{Failure to Prevent Genocide}

Still-and this is the most important and positive contribution of the ICJ's judgment-Belgrade should have seen the massacre coming, yet did nothing to prevent it. As the court recalls, the 1948 UNCG calls upon states to prevent genocide:

In view of their undeniable influence and of the information, voicing serious concern, in their possession, the Yugoslav federal authorities should, in the view of the Court, have made the best efforts within their power to try and prevent the tragic events then taking shape, whose scale, though it could not have been foreseen with certainty, might at least have been surmised. The FRY leadership, and President Milošević above all, were fully aware of the climate of deep-seated hatred which reigned between the Bosnian Serbs and the Muslims in the Srebrenica region. As the Court has noted in paragraph 423 above, it has not been shown that the decision to eliminate physically the whole of the adult male population of the Muslim community of Srebrenica was brought to the attention of the Belgrade authorities. Nevertheless, given all the international concern about what looked likely to happen at Srebrenica, given Milošević's own observations to Mladić, which made it clear that the dangers were 
known and that these dangers seemed to be of an order that could suggest intent to commit genocide, unless brought under control, it must have been clear that there was a serious risk of genocide in Srebrenica. Yet the Respondent has not shown that it took any initiative to prevent what happened, or any action on its part to avert the atrocities which were committed. It must therefore be concluded that the organs of the Respondent did nothing to prevent the Srebrenica massacres, claiming that they were powerless to do so, which hardly tallies with their known influence over the VRS. As indicated above, for a State to be held responsible for breaching its obligation of prevention, it does not need to be proven that the State concerned definitely had the power to prevent the genocide; it is sufficient that it had the means to do so and that it manifestly refrained from using them. ${ }^{76}$

And so Serbia failed to honor this obligation. But because Serbia could not necessarily have prevented the crimes, no reparations or damages were assessed. According to the ICJ, the required nexus for an award of compensation could only be considered "if the Court were able to conclude from the case as a whole and with a sufficient degree of certainty that the genocide at Srebrenica would in fact have been averted if the Respondent had acted in compliance with its legal obligations. However, the court clearly cannot do so."77

This fascinating conclusion seems pregnant with potential for the promotion of human rights and the prevention of atrocities. As the court explains,

[t]he obligation to prevent the commission of the crime of genocide is imposed by the Genocide Convention on any State party which, in a given situation, has it in its power to contribute to restraining in any degree the commission of genocide. [T] he obligation to prevent genocide places a State under a duty to act which is not dependent on the certainty that the action to be taken will succeed in preventing the commission of acts of genocide, or even on the likelihood of that outcome. ${ }^{78}$

Do these powerful words not also apply to France and Belgium, and even the United States, with respect to Rwanda in 1994? And what of Darfur in 2007? As for Srebrenica itself, there is much support within the judgment for the view that if Belgrade should have anticipated the impending atrocities in Srebrenica in July 1995, then so too should others have done. As Judge Keith notes in his individual opinion,

Coming closer to the time of the atrocities, not just the leadership in Belgrade but also the wider international community was alerted to the deterioration of the security situation in Srebrenica by Security Council resolution 1004 (1995) adopted on 12 July 1995 under Chapter VII of the Charter. The Council expressed grave concern at the plight of the civilian population "in and around the safe area of Srebrenica." It demanded, with binding force, the withdrawal of the Bosnian Serb forces from the area and the allowing of unimpeded access for international humanitarian agencies to the area to alleviate the plight of the civilian population. ${ }^{79}$

Certainly the Serbs in Belgrade were not the only ones who might have done more to protect the Muslims of Srebrenica.

On this important point, the ICJ reinforces the "responsibility to protect" set out in the 2005 Outcome Document of the Summit of Heads of State and Government.$^{80}$ But it goes further, elevating the duty to a treaty obligation, and one that is actionable before the ICJ for those states that have ratified the UNCG without reservation to art. 9. But although this development of the law is extremely welcome, the court's refusal to award damages is likely to discourage future recourse based upon this obligation to prevent genocide. Rather, the court's pronouncement strengthens arguments in 
the political sphere, which is where genocide prevention really belongs. When we quarrel about whether genocide has taken place after the atrocities have been committed, it is already too late.

\section{Conclusion}

For decades, human-rights lawyers have looked to art. 9 of the UNCG as a tool with great potential. It has been cited countless times in NGO briefs and held up to cautious states as a remedy they might invoke. There have been several applications, but always by states directly involved in a conflict rather than by those acting erga omnes. None has led to a very productive result. The Bosnia $v$. Serbia case has gone the farthest; it generated two provisional measures requests in 1993 that arguably helped the situation. But the final result, in February 2007, was really a setback for the Bosnian victims, whose lawyers should have convinced the state to discontinue their case. They probably could have obtained useful political considerations from Belgrade in exchange, but they have now, obviously, lost that chance.

In a general sense, the ICJ opted for a restrictive and conservative construction of the definition of genocide set out in art. 2 of the UNCG. Here it goes against the grain of much of the academic literature, characterized by pleas to expand the categories of groups protected by the convention, to reduce the threshold for destruction "in part," and to enlarge the number of punishable acts. Some have argued this can be done by interpretation, while others have called for amendment. ${ }^{81}$ It has always been striking that state practice showed little or no inclination to follow these appeals. The most dramatic example of this was the Rome Conference of June-July 1998, where the definition of genocide drawn from the $1948 \mathrm{UNCG}^{82}$ was incorporated into art. 6 of the Rome Statute with virtually no objection. Only one state, Cuba, suggested that this might be an opportunity to "improve" upon the old definition. ${ }^{83}$

The refusal of the Rome Conference to amend the classic definition of genocide might seem inconsistent with its general approach to subject-matter jurisdiction. The conference effected a dramatic rewrite and expansion of international crimes; for example, it changed the concept of war crimes so as to include internal armed conflict. ${ }^{84}$ Two decades earlier, in adopting Additional Protocol II to the Geneva Conventions, ${ }^{85}$ a diplomatic conference had intentionally rejected the concept of war crimes in internal armed conflict. As recently as 1995, distinguished scholars as well as the International Committee of the Red Cross continued to argue that there was no individual criminal liability under international law for war crimes committed in internal armed conflict. ${ }^{86}$ Four judges of the ICTY Appeals Chamber disagreed, in the first major ruling of that institution. ${ }^{87}$ Astonishingly, the Rome Conference agreed with them, and the law changed forever.

The same amazing transformation occurred with respect to crimes against humanity, the second of the three categories over with the ICC may exercise jurisdiction. Since the concept of crimes against humanity was first set out in positive law at Nuremberg, it had been dogged by the need to link such crimes with aggressive war. As recently as 1993, the UN Security Council reaffirmed the link between crimes against humanity and armed conflict in the text of art. 5 of the Statute of the ICTY. ${ }^{88}$ Here, too, the tribunal's innovative judges moved the goalposts by declaring that there was no such nexus under customary law. ${ }^{89}$ On this point, too, the Rome Conference accepted the new approach.

Why, then, did the conference respond so differently with respect to genocide? Many factors may contribute to an explanation, but the most plausible one is the fact 
that there was no longer any need to amend the definition of genocide. Once crimes against humanity had been cured of its great shortcoming, the link with armed conflict, it quickly occupied the territory that had been reserved for genocide since 1948, namely attacks on minorities committed during peacetime. Moreover, crimes against humanity also adequately covered all those atrocities that lie on the fringes of "pure" genocide, such as ethnic cleansing. Thus, nobody saw any practical need for reform, and the Rome Conference's confirmation of the enduring nature of the 1948 genocide definition was little more than perfunctory. History helpfully explains why the distinction between genocide and crimes against humanity was once so important, and why it is no longer so. ${ }^{90}$

Today, there is only one difference of any significance in terms of the legal effects of describing acts as "genocide" or as "crimes against humanity": the UNCG gives jurisdiction to the ICJ in the event of disputes between states parties, whereas no comparable treaty provision exists for crimes against humanity. Theoretically, even states that have not ratified the UNCG, as long as they have accepted the general jurisdiction of the ICJ, may be sued in that forum for serious violations of international humanitarian law and human-rights law, as the 19 December 2005 judgment in Congo v. Uganda demonstrated. ${ }^{91}$ But since the February 2007 decision in Bosnia v. Serbia, most states will understand that a suit before the ICJ will succeed only in the clearest of cases. The court seems to be saying that international criminal tribunals are the better forum for these debates.

The ICJ's ruling in Bosnia v. Serbia is sure to lead to criticisms that the world's principal judicial institution is innately conservative, a club of former legal advisors and ambassadors zealous to protect the interests of states. That would be unfair, because the court has distinguished itself in recent years with important judgments that have advanced the law of human rights in significant respects. With Bosnia $v$. Serbia, its close adherence to the findings of the ICTY leaves it on reliable ground. Although Bosnia and Herzegovina's claim was rejected in its essential parts, there can be no doubt that Serbia and its proxy within Bosnia and Herzegovina were responsible for war crimes and for crimes against humanity. Again, the ICTY jurisprudence provides all the authority we need for such a proposition. But the claims of genocide never quite added up (with the exception of Srebrenica), and the ICJ had the wisdom and integrity to say as much, even if doing so might make the judges unpopular in some circles.

\section{Notes}

1. Charter of the United Nations, 26 June 1945, http://www.un.org/aboutun/charter/ (accessed 11 May 2007), arts. 92, 93.

2. Convention on the Prevention and Punishment of the Crime of Genocide, 9 December 1948, 78 U.N.T.S. 277, http://www.unhchr.ch/html/menu3/b/p_genoci.htm (accessed 9 May 2007), art. 9.

3. Trial of Pakistani Prisoners of War (Pakistan v. India), Pleadings, Oral Arguments, Documents. Accusations of state responsibility for genocide are as old as the UNCG itself. Even during drafting of the UNCG, in 1948, Pakistan accused India of genocide, notably by Sikhs and Hindus directed against Muslims: UN Doc. A/C.6/SR.63 (Ikramullah, Pakistan). See India's response (UN Doc. A/C.6/SR.64 (Sundaram, India)) and Pakistan's diplomatic refusal to reply (UN Doc. A/C.6/SR.65 (Bahadur Khan, Pakistan)).

4. Case concerning Application of the Convention on the Prevention and Punishment of the Crime of Genocide (Bosnia and Herzegovina v. Yugoslavia), Judgment, 26 February 2007 [Bosnia v. Serbia 2007 Judgment]. 
5. UN Doc. S/RES/827 (1993). See William A. Schabas, The UN International Criminal Tribunals: The Former Yugoslavia, Rwanda, Sierra Leone (Cambridge: Cambridge University Press, 2006).

6. See Peter H. F. Bekker and Paul C. Szasz, "Casenote: Application of the Convention on the Prevention and Punishment of the Crime of Genocide," American Journal of International Law 91 (1997): 121-57; Laurence Boisson de Chazournes, "Les ordonnances en indication de mesures conservatoires dans l'affaire relative à l'application de la convention pour la prévention et la répression du crime de génocide," Annuaire français de droit international 39 (1993): 514-39; Ben Gaffikin, "The International Court of Justice and the Crisis in the Balkans: Application of the Convention on the Prevention and Punishment of the Crime of Genocide (Bosnia and Herzegovina v. Yugoslavia), 32 I.L.M. 1599 (1993)," Sydney Law Review 17 (1995): 458-72; Thomas D. Grant, "Territorial Status, Recognition, and Statehood: Some Aspects of the Genocide Case (Bosnia and Herzegovina v. Yugoslavia), Stanford Journal of International Law 33 (1997): 305-42; Christine Gray, "Application of the Convention on the Prevention and Punishment of the Crime of Genocide (Bosnia and Herzegovina v. Yugoslavia (Serbia and Montenegro))," International and Comparative Law Quarterly 43 (1994): 697-715; William L. Hurlock, "The International Court of Justice: Effectively Providing a Long Overdue Remedy for Engaging State-Sponsored Genocide (Bosnia-Herzegovina v. Yugoslavia)," American University Journal of International Law and Policy 12 (1997): 299-328; Rafaëlle Maison, "Les ordonnances de la Cour international de justice dans l'affaire relative à l'application de la Convention pour la prévention et la répression du crime de génocide," (European Journal of International Law 3 (1994): 381-400; Sandrine Maljean-Dubois, "L'affaire relative à l'application de la Convention pour la prévention et la répression du crime de génocide (Bosnie-Herzégovine c. Yougoslavie), Arrêt du 11 juillet 1996, exceptions préliminaires," Annuaire français de droit international 42 (1996): 357-86. Two members of the original Bosnian legal team have published materials relating to the case: Francis A. Boyle, The Bosnian People Charge Genocide: Proceedings at the International Court of Justice Concerning Bosnia v. Serbia on the Prevention and Punishment of the Crime of Genocide (Amherst, MA: Aletheia Press, 1996); John Quigley, The Genocide Convention: An International Law Analysis (Aldershot, UK: Ashgate Publishing, 2006).

7. Application of the Convention on the Prevention and Punishment of the Crime of Genocide (Bosnia and Herzegovina v. Yugoslavia (Serbia and Montenegro)), Requests for the indication of provisional measures, 8 April 1993, International Court of Justice Reports (1993), 16 [Bosnia v. Serbia Provisional Measures].

8. Bosnia v. Serbia 2007 Judgment, para. 64(q).

9. Bosnia v. Serbia Provisional Measures, 16.

10. Ibid.

11. Application of the Convention on the Prevention and Punishment of the Crime of Genocide (Bosnia and Herzegovina v. Yugoslavia (Serbia and Montenegro)), Further requests for the indication of provisional measures, 13 September 1993, International Court of Justice Reports (1993), 333 [Bosnia v. Serbia Further Provisional Measures].

12. Ibid., 334.

13. Ibid., 336.

14. Ibid., 325 .

15. "Statement of Intention by the Republic of Bosnia and Herzegovina to Institute Legal Proceedings against the United Kingdom before the International Court of Justice, Nov. 15, 1993," UN Doc. A/48/659-S/26806, United Nations Yearbook 47 (1993), 465.

16. Application of the Convention on the Prevention and Punishment of the Crime of Genocide (Bosnia and Herzegovina v. Yugoslavia (Serbia and Montenegro)), Preliminary objections, 11 July 1996, International Court of Justice Reports (1996), 595.

17. Application of the Convention on the Prevention and Punishment of the Crime of Genocide, counter-claims, Order of 17 December 1997, International Court of Justice Reports (1997), 243. 
18. Application for Revision of the Judgment of 11 July 1996 in the Case concerning Application of the Convention on the Prevention and Punishment of the Crime of Genocide (Bosnia and Herzegovina v. Yugoslavia), Preliminary objections (Yugoslavia v. Bosnia and Herzegovina), 3 February 2003, para. 67.

19. Case Concerning Legality of the Use of Force (Serbia and Montenegro v. Belgium et al.), Preliminary objections, 15 December 2004, para. 91.

20. Bosnia v. Serbia 2007 Judgment, paras. 114-39.

21. Ibid., joint dissenting opinion of Judges Ranjeva, Shi, and Koroma; ibid., declaration of Judge Skotnikov; ibid., separate opinion of Judge ad hoc Kreča.

22. France et al. v. Göring et al., (1946) 22 I.M.T. 203, 13 I.L.R. 203; "International Military Tribunal (Nuremberg), Judgments and Sentences (October 1, 1946)," American Journal of International Law 41 (1947): 172-333, 221.

23. James Crawford, The International Law Commission's Articles on State Responsibility: Introduction, Text and Commentaries (Cambridge: Cambridge University Press, 2002), 16-20.

24. Bosnia v. Serbia 2007 Judgment, para. 162.

25. Ibid., para. 166.

26. Ibid., para. 166 .

27. Ibid., para. 179.

28. Ibid., separate opinion of Judge Tomka; ibid., joint declaration of Judges Shi and Koroma; ibid., separate opinion of Judge ad hoc Kreča, paras. 126-29.

29. Ibid., para. 147.

30. Ibid., para. 173 .

31. Ibid., citing Rome Statute of the International Criminal Court, U.N. Doc. A/CONF.183/9 (17 July 1998).

32. See Christian J. Tams, "Article 49," in The Statute of the International Court of Justice: A Commentary, ed. Andreas Zimmerman, Christian Tomuschat, and Karin Oellers-Frahm, 1099-1108 (Oxford: Oxford University Press, 2006).

33. Bosnia v. Serbia 2007 Judgment, dissenting opinion of Vice-President Al-Khasawneh.

34. Prosecutor v. Blaškić, Objection to the issue of subpoenae duces tecum, ICTY-95-14-AR108 (29 October 1997).

35. Art. 72 of the Rome Statute provides that states will determine whether production of evidentiary materials may conflict with national security concerns. If they so judge, the court is without authority to compel production, although it may draw evidentiary inferences from the refusal to produce the materials. See William A. Schabas, "National Security Interests and the Rights of the Accused," in National Security and International Criminal Justice, ed. H. Roggemann and P. Sarcevic, 105-13

(The Hague: Kluwer Law International, 2002).

36. The formulation varies, depending upon the legal system; French law, for example, requires that the judge be convinced of guilt according to his or her intime conviction. In practice, however, the standard is about the same.

37. Rome Statute, art. 66(3).

38. Bosnia v. Serbia 2007 Judgment, para. 210.

39. ICTY, Rules of Procedure and Evidence, UN Doc. IT/32, Rule 87(A).

40. Case concerning Armed Activities on the Territory of the Congo (Democratic Republic of the Congo v. Uganda), 19 December 2005, para. 211 [Congo v. Uganda].

41. Final Report of the United Nations Commission of Experts established pursuant to Security Council Resolution 780 (1992), UN Doc. S/1994/674/Add.2 (28 December 1994).

42. The Situation in Bosnia and Herzegovina, UN General Assembly Resolution 47/121, UN Doc. A/RES/47/121 (18 December 1992).

43. Bosnia v. Serbia Further Provisional Measures, Separate reasons of Judge ad hoc Lauterpacht, 431-32, paras. 68-70.

44. Interim Report by the Commission of Experts Established Pursuant to Security Council Resolution 780 (1992), UN Doc. S/25374 (1993), para. 55. 
45. Quoting UN Doc. A/C.6/234.

46. Bosnia v. Serbia 2007 Judgment, para. 190.

47. Prosecutor v. Krstić, Judgment, ICTY-98-33-T (2 August 2001), para. 562 [Krstić Trial Judgment].

48. Prosecutor v. Stakić, Judgment, ICTY-97-24-T (31 July 2003), para. 519 [Stakić Trial Judgment].

49. Drazen Petrovic, "Ethnic Cleansing: An Attempt at Methodology," European Journal of International Law 5 (1994): 342-59, 342; Catherine A. Mackinnon, "Rape, Genocide and Women's Human Rights," Harvard Women's Law Journal 17 (1994): 5-16, 8; Lori Lyman Bruun, "Beyond the 1948 Convention: Emerging Principles of Genocide in Customary International Law," Maryland Journal of International Law and Trade 17 (1993): 193-226, 200. Also see John Webb, "Genocide Treaty_Ethnic Cleansing-Substantive and Procedural Hurdles in the Application of the Genocide Convention to Alleged Crimes in the Former Yugoslavia," Georgia Journal of International and Comparative Law 23 (1993): 377-408, 402-3.

50. Prosecutor v. Krstić, Judgment, ICTY-98-33-A (19 April 2004) [Krstić Appeals Judgment], Partial dissenting opinion of Judge Shahabuddeen, paras. 45-57.

51. Prosecutor v. Blagojević, Judgment, ICTY-02-60-T (17 January 2005), paras. 659-66 [Blagojević Trial Judgment].

52. Bosnia v. Serbia 2007 Judgment, paras. 186-88.

53. Report of the International Commission of Inquiry on Darfur to the United Nations Secretary-General, Pursuant to Security Council Resolution 1546 of 18 September 2004, UN Doc. S/2005/60 (25 January 2005), para. 184, http://www.un.org/News/dh/sudan/ com_inq_darfur.pdf (accessed 29 May 2007) [COI Report].

54. Bosnia v. Serbia 2007 Judgment, para. 277; see also para. 319.

55. Prosecutor v. Jelisić, Judgment, ICTY-95-10-T (14 December 1999), para. 100 [Jelisić Trial Judgment]; Prosecutor v. Jelisić, Judgment, ICTY-95-10-A (5 July 2001), para. 48.

And crimes against humanity, too: Prosecutor $v$. Kunarac et al., Judgment, ICTY-96-23/1-A (12 June 2002), para. 98, n. 114 [Kunarac Appeals Judgment]. The law has evolved so far in recent years that even mere serial killers, not to mention the Hells Angels and the Mafia, now fit within the parameters of crimes against humanity as interpreted by the ICTY Appeals Chamber. The Darfur Commission cites the famous pronouncement in Kunarac, noting, with respect to its discussion of crimes against humanity, 52, that "[i]t is not necessary, but it may be relevant, to prove the attack is 'the result of the existence of a policy or plan"” COI Report, 52.

56. COI Report, para. 520.

57. Kunarac Appeals Judgment, para. 98, n. 114.

58. “Elements of Crimes," ICC-ASP/1/3 (September 2002), art. 6(a)(4).

59. M. Cherif Bassiouni, The Legislative History of the International Criminal Court: Introduction, Analysis and Integrated Text, vol. 1 (Ardsley, NY: Transnational

Publishers, 2005), 151-52. See also M. Cherif Bassiouni, Crimes against Humanity, 2nd ed. (The Hague: Martinus Nijhoff, 1999), 243-81.

60. Bosnia v. Serbia 2007 Judgment, paras. 276-77; see also paras. 319, 334, 344, 354, 361, 367.

61. Krstić Appeals Judgment; Blagojević Trial Judgment. In May 2007 the Appeals Chamber, citing the ICJ judgment of February 2007, overturned the conviction of Blagojevic on the grounds that he only knew of the ethnic cleansing and not of the mass murders, and therefore could not be held guilty of complicity in genocide. Prosecutor v. Blagojevic, Judgment, ICTY-02-60-A (9 May 2007), para. 123.

62. Jelisić Trial Judgment; Prosecutor $v$. Sikirica et al., Judgment on defence motions to acquit,. ICTY-95-8-T (3 September 2001); Stakić Trial Judgment; Prosecutor v. Brđanin, Judgment, ICTY-99-36-T (1 September 2004) [Brđanin Trial Judgment].

63. Bosnia v. Serbia 2007 Judgment, para. 374.

64. Ibid., paras. 217,374 . 
65. Prosecutor v. Milošević et al., Indictment, ICTY-99-37-PT (24 May 1999).

66. Prosecutor v. Plavšić, Sentencing judgment, ICTY-00-39\&40/1 (27 February 2003).

67. Prosecutor v. Brđanin, Prosecution Notice of Appeal, ICTY-99-36-A (30 September 2005).

68. Prosecutor v. Milošević, Decision on motion for judgment of acquittal, ICTY-02-54-T (16 June 2004).

69. Bosnia v. Serbia 2007 Judgment, para. 249.

70. Ibid., paras. 403-6.

71. Ibid., para. 215 .

72. Ibid., para. 296.

73. Blagojević Trial Judgment.

74. Brđanin Trial Judgment, especially paras. 969-91.

75. Prosecutor $v$. Karamera et al., Decision on prosecutor's interlocutory appeal of decision on judicial notice, ICTR-98-44-AR73(C) (16 June 2006).

76. Bosnia v. Serbia 2007 Judgment, para. 438.

77. Ibid., para. 462.

78. Ibid., para. 461.

79. Ibid., declaration of Judge Keith, para. 11.

80. Outcome Document of the 2005 World Summit, UN Doc. A/RES/60/1 (24 October 2005), paras. 138-139.

81. For various proposals of amendment, see, e.g., Benjamin Whitaker, Revised and Updated Report on the Question of the Prevention and Punishment of the Crime of Genocide, UN Doc. E/CN.4/Sub.2/1985/6 (2 July 1985). For a recent academic example of an expansive approach, see Quigley, Genocide Convention.

82. UNCG, art. 2.

83. Summary Records of the Third Plenary Session of the Diplomatic Conference, UN Doc. A/CONF.183/C.1/SR.3 (16 June 1998), para. 100. See also Report of the Ad Hoc Committee on the Establishment of an International Criminal Court, UN Doc. A/50/22, 12-13, paras. 59-72. Virtually all states that spoke at the diplomatic conference urged incorporation of the UNCG definition without modification: Summary Records, paras. 2, 18, 20 (Germany), 22 (Syria), 24 (United Arab Emirates), 26 (Bahrain), 28 (Jordan), 29 (Lebanon), 30 (Belgium), 31 (Saudi Arabia), 33 (Tunisia), 35 (Czech Republic), 38 (Morocco), 40 (Malta), 41 (Algeria), 44 (India), 49 (Brazil), 54 (Denmark), 57 (Lesotho), 59 (Greece), 64 (Malawi), 67 (Sudan), 72 (China), 76 (Republic of Korea), 80 (Poland), 84 (Trinidad and Tobago), 85 (Iraq), 107 (Thailand), 111 (Norway), 113 (Côte d'Ivoire), 116 (South Africa), 119 (Egypt), 122 (Pakistan), 123 (Mexico), 127 (Libya), 132 (Colombia), 135 (Iran), 137 (United States of America), 141 (Djibouti), 143 (Indonesia), 145 (Spain), 150 (Romania), 151 (Senegal), 153 (Sri Lanka), 157 (Venezuela), 161 (Italy), 166 (Ireland), 172 (Turkey), 174 (comments of the Chair).

84. Rome Statute, art. 8(2)(c-f).

85. Protocol Additional to the 1949 Geneva Conventions and Relating to the Protection of Victims of Non-International Armed Conflicts, 8 June 1977, 1125 U.N.T.S. 609.

86. "Preliminary Remarks on the Setting-Up of an International Tribunal for the Prosecution of Persons Responsible for Serious Violations of International Humanitarian Law Committed in the Territory of the Former Yugoslavia," DDM/JUR/442b (25 March 1993), para. 4; Theodor Meron, "War Crimes in Yugoslavia and the Development of International Law," American Journal of International Law 88 (1994): 76-87, 80.

87. Prosecutor $v$. Tadic, Decision on the defence motion for interlocutory appeal on jurisdiction, ICTY-94-1-AR72 (2 October 1995), para. 137 [Tadić Jurisdiction Decision].

88. Statute of the International Criminal Tribunal for the Former Yugoslavia, UN Doc. S/RES/827 (25 May 1993), Annex, art. 5. See the secretary-general's report: "Crimes against humanity are aimed at any civilian population and are prohibited regardless of whether they are committed in an armed conflict, international or internal in character." Report of the Secretary-General Pursuant to Paragraph 2 of Security Council Resolution 808 (1993), UN Doc. S/25704 (3 May 1993), para. 47. 
89. Tadić Jurisdiction Decision, para. 141. Also see Prosecutor v. Tadić, Judgment, ICTY-94-1-A (15 July 1999), para. 251; Prosecutor v. Kordić et al., Judgment, ICTY-9514/2-T (26 February 2001), para. 23.

90. On this point, the reader is referred to my recent article in this journal: William A. Schabas, "Semantics or Substance? Professor Scheffer's Welcome Proposal to Strengthen Criminal Accountability for Atrocities," Genocide Studies and Prevention 2 (2007): 31-36.

91. Congo v. Uganda; see also Legal Consequences of the Construction of a Wall in the Occupied Palestinian Territory, advisory opinion, International Court of Justice (9 July 2004). 